\title{
Pengembangan Lembar Kerja Peserta Didik (LKPD) Berbasis High Order Thinking Skill (HOTS)
}

\author{
Ade Fitria \\ Pendidikan Kimia, Universitas Negeri Makassar \\ Email: fitriaade.82@gmail.com \\ Muhammad Wijaya \\ Pendidikan Kimia, Universitas Negeri Makassar \\ Email:wijasumi@yahoo.co.id \\ Muhammad Danial \\ Pendidikan Kimia, Universitas Negeri Makassar \\ Email: muh_niels@yahoo.com
}

(Diterima: 18-Desember-2019; direvisi: 19-Januari-2020; dipublikasikan: 18-Maret-2020)

\begin{abstract}
Abstrak: Penelitian ini merupakan penelitian pengembangan yang bertujuan mengembangkan LKPD berbasis HOTS pada materi tabel periodik unsur yang valid, praktis dan efektif digunakan dalam melatih kemampuan berpikir tingkat tinggi peserta didik. Model pengembangan yang digunakan dalam penelitian ini mengacu pada model pengembangan 4-D, yang terdiri dari tahap pendefinisian (define), tahap perancangan (design), tahap pengembangan (develop) dan tahap penyebaran (disseminate). Adapun yang dikembangkan adalah lembar kerja peserta didik (LKPD) berbasis HOTS. LKPD berbasis HOTS yang dikembangkan, kemudian divalidasi oleh dua orang ahli. Setelah validasi, lalu dilakukan uji coba yang dilakukan di SMA Negeri 2 Enrekang pada kelas X MIPA 6 dengan jumlah peserta didik sebanyak 34 orang. Hasil penelitian menunjukkan bahwa LKPD yang dihasilkan valid dengan nilai rata-rata kevalidan sebesar 3,73 dengan kriteria sangat valid. Kriteria praktis dan efektif juga terpenuhi, uji kepraktisan meliputi: (1) keterlaksanaan LKPD berbasis HOTS berada pada nilai rata-rata $\mathrm{M}=1,79$ dalam kategori $(1,5 \leq \mathrm{M} \leq 2,0)$ yang artinya aspek dan kriteria yang diamati berada pada kategori terlaksana seluruhnya, (2) peserta didik memberikan respon yang positif dengan persentase $47,06 \%$ sangat positif, $51,52 \%$ merespon positif dan (3) guru memberikan respon yang sangat positif dengan nilai rata-rata 3,42 yang berarti praktis dan tidak direvisi. LKPD berbasis HOTS ini juga memenuhi kriteria keefektifan, dengan hasil: (1) aktivitas belajar peserta didik dengan rata-rata 93 termasuk kriteria sangat aktif, (2) hasil belajar peserta didik memenuhi kriteria efektif dimana diperoleh rata-rata 58 dengan kriteria level kemampuan berpikir tingkat tinggi menurut Lewy (51-75) berada pada kategori baik. Dengan demikian, dapat disimpulkan bahwa produk LKPD berbasis HOTS yang dikembangkan termasuk valid, praktis, dan efektif.
\end{abstract}

Kata kunci: Pengembangan LKPD Berbasis HOTS; Tabel Periodik Unsur.

Abstract: This study is research development, which aims at developing LKPD (worksheets) based on HOTS on periodic table of elements material which is valid, practical, and effective to be used in training higher-order thinking skills. The development model used in this study refers to 4-D development model, which consists of defining stage (define), designing stage (design), development stage (develop), and dissemination stage (disseminate). The devices developed are LKPD based on HOTS. LKPD based on HOTS which is developed is then validated by two experts. After being validated, the devices are tested at SMAN 2 Enrekang in 
grade X MIPA 6 with 34 students. The results of the study reveal that the resulting LKPD is valid with mean score of validation is 3.73 which is in very valid category. The practical and effective criterion are also met, the practicality test includes, (1) the implementation of LKPD based on HOTS is in the mean $\mathrm{M}=1.79$ in category $(1.5 \leq \mathrm{M} \leq 2.0)$ meaning that the aspect and criteria being observed is in entirely implemented category, (2) the students gave positive response with $47.06 \%$ which is very positive, $51.52 \%$ gave positive response, and (3) the teacher gave very positive response with the mean score of 3.42 which is practical and no revision. The LKPD based on HOTS has met effective criteria with the following results (1) the students' learning activity is in the average of 93 which is very active category, (2) the students' learning result has met effective criteria which obtained the mean score of 58 with the criteria of high level thinking skill level according to Lewy (51-75) which is in good category. Therefore, the conclusion is the product of LKPD based on HOTS developed is valid, practical, and effective.

Keywords: Students Worksheet Development Based on HOTS; Elements Periodic Table.

\section{PENDAHULUAN}

Pendidikan sangat penting untuk membentuk karakter, mental, dan potensi manusia dalam menghadapi tuntutan hidup. Melalui pendidikan, peserta didik diharapkan menjadi manusia yang lebih baik dan memiliki talenta yang dapat digunakan untuk menghadapi tuntutan kehidupan. Berdasarkan Permendikbud No. 21 tahun 2016 tentang Standar Isi Pendidikan Dasar dan Menengah menyatakan bahwa kebutuhan kompetensi masa depan peserta didik ialah peserta didik yang dapat memiliki kemampuan berpikir tingkat tinggi atau High Order Thinking Skill (HOTS). Namun demikian, pada kenyataannya peserta didik masih kurang diarahkan untuk dapat menguasi kemampuan berpikir tingkat tinggi.

Kurikulum 2013 yang diterapan sekarang di Indonesia dirancang sebagai peningkatan kemampuan peserta didik dalam berpikir kritis dan kreatif. Dimana, berpikir kritis dan kreatif merupakan bagian dari kemampuan berpikir tingkat tinggi (HOTS). Sehingga, kemampuan berpikir tingkat tinggi (HOTS) sangat diperlukan peserta didik dalam menghadapi era pendidikan di masa yang akan datang.

Keterampilan berfikir ialah istilah yang melibatkan dimensi beberapa proses kognitif. HOTS merupakan suatu kemampuan berpikir yang tidak hanya membutuhkan kemampuan mengingat saja, namun membutuhkan kemampuan lain yang lebih tinggi, seperti kemampuan berfikir kreatif dan kritis (Brookhart, 2010).

HOTS membuat peserta didik lebih baik dalam memakai informasi. mudah untuk menjadi penerima pasif informasi dikarenakan berfikir tingkat tinggi tidak terlibat. Banyak kelas yang menjadi penerima pasif informasi, yang mana beberapa guru jatuh kedalam perangkap untuk mengatakan peserta didik apa itu berfikir diganti dengan bagaimana berfikir untuk diri mereka. HOTS mengakibatkan peserta didik mengalami perubahan dan mengharuskan mereka menjadi pembelajar yang aktif. Pembelajaran aktif merupakan pekerjaan yang susah, tapi juga mengembirakan dan menarik (Conklin \& Materials, 2012).

$$
\text { Penggunaan HOTS sebagai }
$$

fundamental untuk mengedukasi peserta didik. Proses mengajar dengan banyak menghubungkan atau tidak menghubungkan dengan fakta bukan berarti guru tersebut telah memberikan suatu hal yang diperlukan oleh peserta didik dalam memahami. Setiap masalah yang akan diselesaikan oleh peserta didik menghasilkan sebuah kesempatan untuk memanfaatkan HOTS untuk pemahaman lebih mendalam. Namun, hal ini tidak akan terjadi dengan sendirinya, guru harus memanfaatkan kesempatan ini untuk mendorong peserta didik dalam berpikir (Conklin \& Materials, 2012). 
LKPD merupakan salah satu sarana untuk membantu dan mempermudah dalam kegiatan pembelajaran sehingga akan terbentuk interaksi yang efektif antara peserta didik dengan pendidik sehingga dapat meningkatkan aktifitas peserta didik dalam meningkatkan kemampuan berfikir. Kemampuan memecahkan masalah yang ada dalam LKPD tersebut yang akan mempengaruhi HOTS peserta didik. LKPD merupakan materi ajar yang dikemas sedemikian rupa agar peserta didik dapat mempelajari materi tersebut secara mandiri, sehingga peserta didik jadi lebih aktif untuk memecahkan masalah yang ada melalui kegiatan diskusi kelompok, praktikum, dan kegiatan menjawab permasalahan yang berhubungan dengan kehidupan sehari-hari. Hal ini menjadikan peserta didik akan lebih tertantang dalam proses kegiatan pembelajaran yang hanya sekedar satu arah saja. Kegiatan memecahkan masalah yang ada dalam LKPD tersebut yang nantinya dapat berimbas pada peningkatan cara berpikirnya termasuk berpikir kritis (Astuti, Danial, \& Anwar, 2018).

Berdasarkan penelitian yang dilakukan oleh Ubaidillah (2016), yang berjudul "Pengembangan LKPD Fisika Berbasis Problem Solving untuk Meningkatkan Keterampilan Proses Sains dan Keterampilan Berpikir Tingkat Tinggi", menunjukkan bahwa dengan penggunaan LKPD Fisika berbasis Problem Solving akan meningkatkan HOTS peserta didik.

LKPD yang digunakan guru untuk menilai hasil belajar peserta didik pada aspek kognitif biasanya diambil dari berbagai buku paket atau LKS yang dibeli. Soal-soal yang terdapat pada LKPD tersebut berupa uraian. Jenis pertanyaan yang diajukan atau tugas yang diberikan oleh guru sangat berpengaruh terhadap perkembangan keterampilan berpikir peserta didik. Pertanyaan atau tugas tersebut bukan hanya untuk memfokuskan peserta didik pada kegiatan, tetapi juga untuk menggali potensi belajar mereka. Pertanyaan atau tugas yang memicu peserta didik untuk berpikir analitis, evaluatif, dan kreatif dapat melatih peserta didik dalam keterampilan berpikir tingkat tinggi.

Bahan pembelajaran berkedudukan sebagai alat atau sarana untuk mencapai standar yang ingin dicapai. Salah satu bahan pembelajaran yang dapat digunakan yaitu LKPD. LKPD merupakan bahan pembelajaran yang dikembangkan oleh guru sebagai fasilitator dalam pembelajaran. LKPD berisi tugas yang harus dikerjakan oleh peserta didik sebagai bentuk latihan yang bertujuan agar peserta didik dapat memahami dan mengerti tentang materi yang diajarkan. LKPD adalah lembaranlembaran berisi tugas yang harus dikerjakan oleh peserta didik yang isinya berupa petunjuk atau langkah-langkah penyelesaian suatu tugas sesuai kompetensi yang akan dicapai (Prastowo, 2014).

Berdasarkan penelitian yang dilakukan oleh Verdina, Gani, \& Sulastri (2018), yang berjudul Improving students' higher order thinking skills in thermochemistry concept using worksheets based on 2013 curriculum menunjukkan bahwa dengan menggunakan student worksheet atau LKPD dapat meningkatkan HOTS peserta didik. Seperti halnya pada materi sistem periodik unsur yang merupakan materi yang berisi konsepkonsep dasar kimia. Sehingga, materi sistem periodik unsur juga bisa diajarkan dengan menggunakan LKPD. LKPD yang sesuai akan dapat membuat peserta didik untuk lebih memahami materi tersebut.

Pengembangan LKPD berbasis HOTS akan membantu dalam meningkatkan kemampuan berpikir peserta didik untuk menguasai konsep terutama dalam HOTS. LKPD yang dikembangkan berisi tugas/latihan yang harus dikerjakan oleh peserta didik, dimana tugas/latihan dalam LKPD berbentuk soal HOTS. Melalui soalsoal latihan tersebut, maka HOTS peserta didik akan terlatih. Sehingga kemampuan berpikir peserta didik akan meningkat.

LKPD berbasis HOTS yang dikembangkan merujuk pada sintaks dari model pembelajaran discovery learning. Sintaks discovery learning dipilih karena 
model discovery learning merupakan model pembelajaran dimana peserta didik memperoleh konsep-konsep dengan cara menemukan sendiri, dengan mengembangkan kemampuan intelektual berpikirnya sehingga mampu memecahkan masalah secara ilmiah. Peserta didik diharapkan dapat menyelidiki mengapa suatu peristiwa dapat terjadi, mengumpulkan data, dan mengolah datanya secara ilmiah untuk menemukan jawaban dari suatu permasalahan.

Model discovey learning ini mementingkan pentingnya pemahaman struktur atau ide-ide penting terhadap suatu disiplin ilmu, melalui keterlibatan peserta didik secara aktif dalam proses pembelajaran. Dalam pembelajaran berbasis penemuan, peserta didik di dorong untuk belajar dengan sebagian besar melalui keterlibatan aktif mereka sendiri di mana guru sebagai fasilitator bagi peserta didik untuk memiliki pengalaman dan melakukan percobaan yang memungkinkan mereka menemukan pengetahuan untuk diri mereka sendiri (Hosnan, 2014).

Latihan-latihan soal yang di berikan kepada peserta didik di sekolah cenderung lebih menguji aspek ingatan dan memahami yang kurang melatih peserta didik dalam melatih HOTS. Sesuai dengan hasil penelitian yang dijabarkan diatas maka peneliti merasa perlu adanya pengembangan bahan ajar berupa LKPD berbasis HOTS.

Tabel periodik unsur merupakan salah satu materi kimia yang diajarkan pada awal semester ganjil pada kelas X SMA. Materi ini merupakan dasar dari pembelajaran kimia oleh karena itu peserta didik diharuskan memahami konsep yang ada pada materi ini secara mendalam sehingga jika nantinya diberikan latihan atau tes peseta didik dapat menjawabnya dengan mudah selain itu peserta didik akan mudah dalam mempelajari materi-materi kimia selanjutnya. Kenyataannya masih ada peserta didik yang belum memahami materi ini dan menyebabkan miskonsepsi saat mempelajari materi kimia selanjutnya. Hal inilah yang menyebabkan banyak peserta didik tidak berminat untuk mempelajari kimia. Salah satu cara untuk membantu peserta didik dalam memahami materi ini yaitu dengan menggunakan LKPD.

Berdasarkan masalah yang ada maka dilakukan penelitian pengembangan Lembar Kerja Peserta Didik (LKPD) berbasis Kemampuan berpikir tingkat tinggi (HOTS) pada materi tabel periodik unsur. LKPD berbasis HOTS yang dikembangkan bertujuan untuk (1) mengembangkan LKPD berbasis HOTS pada meteri tabel periodik unsur; (2) mengetahui kevalidan, kepraktisan, dan keefektifan LKPD berbasis HOTS yang dikembangkan pada materi tabel periodik unsur; (3) memperoleh LKPD berbasis HOTS yang dapat melatih kemampuan berpikir tingkat tinggi peserta didik.

\section{METODE}

Jenis penelitian yang digunakan dalam penelitian ini adalah penelitian pengembangan (Research and Development). Produk yang dikembangkan adalah LKPD berbasis HOTS yang dapat melatih HOTS peserta didik. Adapun model pengembangan yang digunakan yaitu model 4-D dengan 4 tahap pengembangan (1) tahap pendefinisian (define); (2) tahap perancangan (design); (3) tahap pengembangan (develop); dan (4) tahap penyebaran (disseminate). Uji coba dilakukan di SMAN 2 Enrekang pada kelas $\mathrm{X}$ MIPA 6 dengan jumlah peserta didik sebesar 34 orang tahun ajaran 2019/2020.

Teknik pengumpulan data dengan menggunakan (1) instrumen kevalidan yaitu format validasi; (2) instrumen kepraktisan yaitu lembar keterlaksanaan LKPD berbasis HOTS, lembar angket respon peserta didik dan respon guru; (3) instrumen keefektifan yaitu lembar observasi aktivitas peserta didik dan tes hasil belajar.

Teknik analisis yang digunakan pada penelitian ini dikelompokkan menjadi tiga yaitu analisis data kevalidan LKPD berbasis HOTS, analisis data kepraktisan LKPD berbasis HOTS, dan analisis data keefektifan LKPD berbasis HOTS. 
HASIL DAN PEMBAHASAN

\section{Proses Pengembangan LKPD Berbasis HOTS dan Kualitas Produk LKPD Berbasis HOTS}

\section{Tahap Pendefinisian (Define)}

bertujuan untuk menetapkan dan mendefinisikan kebutuhan-kebutuhan pembelajaran dengan menganalisis tujuan dan batasan materi. Pada tahap ini dilakukan wawancara dan observasi langsung dengan guru kimia. Adapun langkah-langkahnya adalah analisis awal-akhir, analisis peserta didik, analisis konsep/materi, perumusan tujuan pembelajaran. Tahap perancangan (Design) bertujuan merancang LKPD berbasis HOTS untuk meningkatkan HOTS . Kegiatan yang dilaksanakan pada tahap ini, meliputi penyusunan bahan ajar LKPD berbasis HOTS, pemilihan format, dan rancangan (desain) awal. Tahap ini selain pembuatan LKPD berbasis HOTS dibuat juga instrument-instrumen pendukung yaitu RPP dan Tes hasil belajar. Selain itu dibuat juga instrumen-instrumen untuk menilai kualitas perangkat pembelajaran yang dikembangkan meliputi tiga macam, yaitu instrumen kevalidan, instrumen kepraktisan, dan instrumen keefektifan. Tahap pengembangan (Develop), kegiatan yang dilakukan pada tahap ini adalah validasi perangkat pembelajaran dan seluruh instrument kepraktisan dan keefektifan perangkat pembelajaran yang telah dibuat. Selain memvalidasi perangkat pembelajaran dan instrument kepraktisan dan keefektifan, dilakukan juga tahap uji coba untuk mengetahui apakah LKPD yang dikembangkan efektif dan praktis.

Validasi ahli, tahap ini bertujuan untuk menghasilkan Lembar Kerja Peserta Didik (LKPD) berbasis HOTS yang valid menurut para ahli. Validasi ini bertujuan untuk menilai kualitas perangkat pembelajaran yang telah dikembangkan. Selain perangkat, intrumen kepraktisan dan keefektifan yang akan digunakan akan divalidasi juga. Validasi perangkat pembelajaran yang dikembangkan divalidasi oleh dua orang dosen kimia UNM yang ahli di bidangnya. Hasil validasi para ahli digunakan sebagai dasar untuk melakukan revisi perangkat pembelajaran. Jadi, dalam melakukan revisi penulis mengacu pada saran-saran serta petunjuk dari para ahli. Adapun data kevalidan secara ringkas dapat dilihat pada Tabel 1.

Tabel 1. Data Kevalidan

\begin{tabular}{lcc}
\hline \multicolumn{1}{c}{ Perangkat dan Instrumen } & Nilai & Ket. \\
\hline LKPD berbasis HOTS & 3,63 & Sangat valid \\
RPP & 3,75 & Sangat valid \\
Tes Hasil Belajar & 3,73 & Sangat valid \\
Lembar observasi ketelaksanaan LKPD berbasis HOTS & 3,75 & Sangat valid \\
Lembar observasi respon peserta didik & 3,78 & Sangat valid \\
Lembar observasi respon guru & 3,75 & Sangat valid \\
Lembar observasi aktivitas peserta didik & 3,78 & Sangat valid \\
\hline
\end{tabular}

Berdasarkan hasil diatas, dapat disimpulkan bahwa kedua validator ahli menyatakan bahwa LKPD berbasis HOTS yang dikembangkan dan instrumeninstrumen yang digunakan telah memenuhi kriteria kevalidan dengan kategori sangat valid.

Uji coba terbatas, hasil revisi yang telah dilakukan setelah proses validasi kemudian disebut dengan prototype II.
Prototype II kemudian digunakan untuk uji coba terbatas terhadap LKPD berbasis HOTS tujuannya untuk mengetahui LKPD yang telah dikembangkan benar-benar sesuai dengan kebutuhan pengguna. Selain itu tahap ini juga untuk mengetahui tingkat kepraktisan dan keefektifan dari LKPD yang dikembangkan. Uji coba terbatas dilakukan di SMAN 2 Enrekang pada tahun ajaran 2019/2020. Subjek uji coba terhadap LKPD 
yang dikembangkan adalah kelas X MIPA 6 dengan jumlah peserta didik sebanyak 34 orang. Pelaksanaan uji coba ini dilakukan dengan melakukan proses pembelajaran sebanyak 4 pertemuan dan 1 pertemuan untuk THB dimulai dari tanggal 3 September 2019 sampai 1 Oktober 2019.
Berdasarkan tahap uji coba yang dilakukan didapatkan data kepraktisan dan keefektifan dari LKPD yang dikembangkan. Berdasarkan hasil analisis data para pengamat tentang keterlaksanaan LKPD berbasis HOTS pada kelas X MIPA 6 dapat dilihat pada Tabel 2.

Tabel 2. Hasil Observasi Keterlaksanaan LKPD berbasis HOTS

\begin{tabular}{lcc}
\hline \multicolumn{1}{c}{ Aspek } & Penilaian & Kategori \\
\hline Sintaks pembelajaran & 1,88 & Terlaksana Seluruhnya \\
Interaksi sosial & 1,72 & Terlaksana Seluruhnya \\
Prinsip reaksi & 1,71 & Terlaksana Seluruhnya \\
Sistem pendukung & 1,83 & Terlaksana Seluruhnya \\
\hline \multicolumn{1}{c}{ Rata-rata total } & 1,79 & Terlaksana Seluruhnya \\
\hline
\end{tabular}

Berdasarkan hasil analisis hasil observasi keterlaksanaan LKPD berbasis HOTS menunjukkan bahwa nilai rata-rata yang didapatkan dari tiap aspek yaitu 1,79 dengan skala kategori $(1,5 \leq \mathrm{M} \leq 2,0)$ yang artinya aspek-aspek yang diamati pada pelaksanaan LKPD berbasis HOTS berada pada kategori terlaksana seluruhnya.
Data respon peserta didik diperoleh melalui angket respon peserta didik terhadap LKPD berbasis HOTS. Angket respon peserta didik dibagikan pada akhir proses pembelajaan tepatnya sebelum tes hasil belajar diberikan. Hasil analisis data respon peserta didik terhadap LKPD berbasis HOTS diisi oleh 34 orang peserta didik dan hasilnya dapat dilihat pada Tabel 3.

Tabel 3. Hasil Analisis Respon Peserta Didik LKPD Berbasis HOTS

\begin{tabular}{ccc}
\hline Kategori & Jumlah Responden & Persentase (\%) \\
\hline Sangat Setuju & 16 & 47,06 \\
Setuju & 17 & 51,52 \\
Tidak Setuju & 1 & 2,94 \\
Sangat Tidak Setuju & 0 & 0 \\
\hline
\end{tabular}

Berdasarkan tabel 3 bahwa persentase rata-rata respon peserta didik terhadap penggunaan LKPD berbasis HOTS di kelas X MIPA 6 memiliki nilai 47,06\% yang menjawab sangat setuju (sangat merespon), dan $2,94 \%$ menjawab pada kategori tidak setuju. Berdasarkan hasil analisis data respon peserta didik terhadap
LKPD berbasis HOTS yang dikembangkan, dapat disimpulkan peserta didik memberikan respon positif terhadap LKPD berbasis HOTS. Lembar respon guru terhadap LKPD berbasis HOTS diberikan kepada 2 guru kimia. Berdasarkan hasil analisis data, respon guru terhadap LKPD berbasis HOTS dapat dilihat pada Tabel 4.

Tabel 4. Hasil Analisis Respon Guru terhadap LKPD Berbasis HOTS

\begin{tabular}{|c|c|c|}
\hline Aspek & Penilaian & Kategori \\
\hline LKPD & 3,32 & Praktis dan tidak direvisi \\
\hline ТHB & 3,50 & Praktis dan tidak direvisi \\
\hline Proses Pembelajaran & 3,44 & Praktis dan tidak direvisi \\
\hline Rata-rata total & 3,42 & Praktis dan tidak direvisi \\
\hline
\end{tabular}


Berdasarkan hasil analisis respon guru di atas, dapat disimpulkan bahwa respon guru terhadap LKPD berbasis HOTS yang dikembangkan praktis dan tidak direvisi dengan nilai rata-rata total aspek yaitu 3,42 dengan kategori "praktis dan tidak direvisi".

Berdasarkan keseluruhan aspek kepraktisan yang dianalisis dapat disimpulkan bahwa LKPD berbasis HOTS yang dikembangkan dalam penggunaannya memenuhi tingkat kepraktisan. Adapun masukan dan saran dari pengamat yaitu perlu memperhatikan alokasi waktu dalam setiap fase kerja kelompok dan verifikasi dari peserta didik agar lebih efektif dan efesien selama proses pembelajaran serta selalu mengontrol keaktifan peserta didik dalam bekerja dengan kelompoknya.

Data aktivitas peserta didik diperoleh melalui observasi yang dilakukan oleh dua orang pengamat. Pengamatan aktivitas peserta didik dilakukan dengan mengamati peserta didik dalam setiap kelompok. Pengamatan dilakukan oleh pengamat kepada peserta didik berdasar pada lembar observasi aktivitas peserta didik selama proses pembelajaran berlangsung dan tiap pertemuan dimana pertemuan dilakukan sebanyak 4 kali. Berdasarkan hasil analisis pengamatan aktivitas peserta didik dapat disimpulkan bahwa peserta didik sangat aktif pada tiap pertemuan. Hasil analisis tiap pertemuan dapat dilihat pada Tabel 5.

Tabel 5. Hasil Analisis Aktivitas Peserta Didik Tiap Pertemuan

\begin{tabular}{|c|c|c|c|c|c|c|c|c|c|c|c|c|}
\hline \multirow{2}{*}{$\begin{array}{c}\text { Pertemuan } \\
\text { Ke - }\end{array}$} & \multicolumn{10}{|c|}{ Kategori Aktivitas (\%) } & \multirow{2}{*}{$\begin{array}{c}\text { Rata- } \\
\text { rata }\end{array}$} & \multirow{2}{*}{ Kategori } \\
\hline & 1 & 2 & 3 & 4 & 5 & 6 & 7 & 8 & 9 & $\mathbf{1 0}$ & & \\
\hline Pertemuan I & 100 & 97 & 100 & 97 & 100 & 97 & 93 & 99 & 82 & 12 & 96 & taktif \\
\hline Pertemuan II & 88 & 91 & 100 & 94 & 100 & 91 & 79 & 97 & 78 & 15 & 91 & at aktif \\
\hline Pertemuan III & 88 & 91 & 100 & 94 & 100 & 91 & 79 & 97 & 82 & 15 & 92 & Sangat aktif \\
\hline Pertemuan IV & 97 & 96 & 100 & 96 & 100 & 93 & 82 & 96 & 82 & 15 & 93 & Sangat aktif \\
\hline Rata-rata & 93 & 94 & 100 & 95 & 100 & 93 & 83 & 97 & 81 & 14 & 93 & Sangat aktif \\
\hline
\end{tabular}

Berdasarkan data tersebut, dapat disimpulkan bahwa LKPD berbasis HOTS yang dikembangkan dapat mengaktifkan peserta didik sehingga HOTSnya terlatih. Adapun rata-rata presentasi aktivitas peserta didik tiap pertemuan yaitu $93 \%$ dengan kategori sangat aktif. Tes hasil belajar yang dilakukan untuk mengukur HOTS peserta didik setelah peserta didik melatih kemampuan berpikirnya melalui proses pembelajaran yang dilakukan dengan menggunakan LKPD berbasis HOTS. Soal tes hasil belajar yang diberikan berbentuk essay/uraian sebanyak 10 nomor. Hasil analisis tes hasil belajar peserta didik dapat dilihat pada Tabel 6 .

Tabel 6. HOTS Peserta Didik Berdasarkan Kategori Level HOTS Lewy

\begin{tabular}{cc}
\hline Kategori & Jumlah Peserta didik \\
\hline Sangat Baik & 5 \\
Baik & 17 \\
Cukup & 12 \\
Kurang & 0 \\
\hline Total & 34 \\
\hline
\end{tabular}

Berdasarkan hasil diatas, nilai ratarata tes hasil belajar peserta didik yang didapatkan sebesar 58. Hasil ini kemudian kemudian dikaitkan dengan kategori level
HOTS dari Lewy sehingga didapatkan hasil bahwa rata-rata HOTS peserta didik kelas X MIPA 6 berada pada kategori baik. Sehingga dapat dinyatakan bahwa LKPD berbasis 
HOTS efektif untuk digunakan. Berdasarkan uraian dapat disimpulkan bahwa LKPD berbasis HOTS efektif untuk digunakan dalam melatih peserta didik untuk berpikir tingkat tinggi (HOTS). Keefektifan LKPD berbasis HOTS merupakan gambaran bahwa secara umum peserta didik telah terlatih dalam berpikir tingkat tinggi sehingga mampu meningkatkan kualitas pembelajaran.

Tahap penyebaran (Disseminate), tahap ini dilakukan agar produk dapat dimanfaatkan oleh orang lain. LKPD yang telah dikembangkan dan dinyatakan valid, efektif, dan praktis dapat disebar. Penyebaran dilakukan dengan mencetak LKPD berbasis HOTS dan dibagikan kepada guru agar dapat digunakan dalam kelas mereka. Selain LKPD, RPP dan THB yang menunjang LKPD berbasis HOTS juga disebar ke guru-guru kimia.

\section{Profil Produk LKPD Berbasis HOTS}

Produk yang dihasilkan dari penelitian ini merupakan LKPD yang mampu atau dapat digunakan untuk melatih peserta didik dalam berpikir tingkat tinggi sehingga HOTS peserta didik dapat terlatih. Produk LKPD berbasis HOTS yang dikembangkan mengacu pada sintaks model pembelajaran discovery learning untuk memudahkan proses melatih HOTS peserta didik. Materi yang dipilih pada pembuatan LKPD berbasis HOTS ini adalah materi Tabel Periodik Unsur. Materi tabel periodik unsur merupakan materi yang berisi konsepkonsep paling dasar yang harus dikuasai oleh peserta didik agar memudahkan peserta didik dalam mempelajari kimia kedepannya. Sintaks discovery learning dipilih karena model pembelajaran discovery learning merupakan model pembelajaran dimana peserta didik memperoleh konsep-konsep dengan cara menemukan sendiri, dengan mengembangkan kemampuan intelektual berpikirnya sehingga mampu memecahkan masalah secara ilmiah.

\section{SIMPULAN DAN SARAN}

Berdasarkan hasil penelitian dan pembahasan, maka dapat disimpulkan bahwa proses pengembangan LKPD berbasis HOTS mengacu pada model pengembangan $4-\mathrm{D}$, yang terdiri dari 4 tahap meliputi 1) tahap pendefinisian (Define), 2) tahap perancangan (Design), 3) tahap pengembangan (Develop) yang terdiri dari dua langkah, yaitu validasi ahli dan uji coba terbatas di SMAN 2 Enrekang, serta 4) tahap penyebaran. Selanjutnya semua desain awal divalidasi oleh ahli, dan berada pada kategori sangat valid, kemudian diujicobakan untuk mengetahui kepraktisan dan keefektifan, sehingga layak digunakan dalam proses pembelajaran. Kualitas LKPD berbasis HOTS yakni a) sangat valid berdasarkan penilaian oleh ahli dengan nilai rata-rata 3,73 (kriteria sangat valid) sedikit revisi, b) praktis karena seluruh aspek pembelajaran dapat terlaksana dengan nilai rata-rata 1,79 (terlaksana seluruhnya), serta mendapat respon sangat positif dari peserta diidk dengan persentase sebesar 47,06\% sangat positif dan $51,51 \%$ positif dan guru dengan nilai rata-rata 3,42 yang berarti praktis dan tidak direvisi, dan 3) efektif karena LKPD berbasis HOTS yang telah dikembangkan mampu mengaktifkan peserta didik dengan rata-rata 93 artinya peserta didik sangat aktif dan efektif dalam melatih kemampuan berpikir tingkat tinggi peserta didik dengan nilai tes hasil belajar peserta didik sebesar 58 dengan kategori HOTS baik.

\section{DAFTAR RUJUKAN}

Astuti, S., Danial, M., \& Anwar, M. 2018. Pengembangan LKPD Berbasis PBL untuk Meningkatkan Keterampilan Berpikir Kritis Peserta Didik pada Materi Kesetimbangan Kimia. Chemistry Education Review (CER), 1(2), 90-114.

Brookhart, S. M. 2010. How To Assess Higher-Order Thingking Skills In Your Classroom. United States of Amerika: ASCD Member Book.

Conklin, W., \& Materials, T. C. 2012. Strategies for Developing HigherOrder Thinking Skills: Grades 6-12. Shell Education. 
Fitria, Wijaya, Danial. Pengembangan lembar kerja....

Hosnan. 2014. Pendekatan Saintifik dan Kontekstual dalam Pembelajaran Abad 21. Kunci Sukses Implementasi Kurikulum 2013. Jakarta: Ghalia Indonesia.

Kementerian Pendidikan dan Kebudayaan. 2016. Peraturan Menteri Pendidikan dan Kebudayaan Nomor 21 Tahun 2016 tentang Standar Isi Pendidikan Dasar dan Menengah. Jakarta: Kemdikbud.

Prastowo, A. 2014. Pengembangan Bahan Ajar Tematik Tinjauan Teoritis dan Praktik. Jakarta: Kencana.

Ubaidillah, M. 2016. Pengembangan LKPD Fisika Berbasis Problem Solving untuk Meningkatkan Keterampilan Proses Sains dan Keterampilan Berpikir Tingkat Tinggi. Jurnal EduFisika, 1(2), 9-20.

Verdina, R., Gani, A., \& Sulastri. 2018. Improving Student's Higher Order Thinking Skills in Thermochemistry Concept Using Worksheets Based on 2013 Curriculum. Journal of Physics: Conference Series, 1088(1), 1-6. 